\title{
IMPLEMENTASI BUDAYA ORGANISASI DALAM PENINGKATAN PELAYANAN ADMINISTRASI PENDIDIKAN DI MAN I MAKASSAR
}

\author{
M. AHSAN AGUSSALIM, ARIFUDDIN SIRA, LA ODE ISMAIL AHMAD \\ Fakultas Tarbiyah dan Keguruan UIN Alauddin Makassar \\ J. HM. Yasin Limpo No. 36 Makassar \\ Email: mahsan@gmail.com, arifuddin.siraj@uin-alauddin.ac.id, \\ laode.ismail@uin-alauddin.ac.id
}

\begin{abstract}
:
This study aims (1) to find out the organizational culture implemented in MAN I Makassar (2) the administrative service system in MAN 1 Makassar (3) the impact of implementing organizational culture in improving administrative services in MAN 1 Makassar. This study uses qualitative methods and phenomenological, pedagogical, sociological and psychological approaches. To obtain data, the author have interviews, observation, documentation and triangulation. The results of this study indicate that the implementation 1 Makassar has been well implemented which takes the form of the of organizational culture in improving administration services at MAN application of a culture of discipline and cooperation that refers to the values of social relations and good communication among personal peers who have been determined to achieve aim. Efforts to improve administrative services observed at MAN 1 Makassar have demonstrated their quality, one of which is to prove harmoniously a relationship between fellow personalities, from students, employees, teachers, and principals, which can be realized in the form of cooperation, both in nature structural and cultural. The implication of this research is that it is expected that the school of Madrasah Aliyah Negeri 1 Makasssar can improve its administrative services while still referring to human values and also can be applied effectively and efficiently.
\end{abstract}

Keywords: Organizational Culture, Administrative Services

\section{PENDAHULUAN}

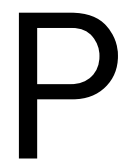

enyelenggaraan pendidikan dalam sebuah organisasi menunjukkan bahwa keberadaan organisasi pendidikan tersebut ditujukan untuk mencapai tujuan pendidikan secara lebih efektif dan efisien. Tujuan pendidikan dan tujuan sekolah sebagai organisasi pendidikan formal tidaklah terpisah. Pendidikan ditujukan bagi orang-orang yang mengikuti proses pendidikan. Proses pendidikan ini berada dalam organisasi. Dengan demikian, keberlangsungan proses pendidikan ini menjadi dasar bagi penetapan tujuan sekolah sebagai sebuah organisasi (Tim Dosen Admanistrasi Pendidikan Indonesia).

Nevizond chatab menyatakan keberlangsungan proses pendidikan dalam sebuah organisasi akan melahirkan budaya organisasi. Budaya organisasi ini sangat berpengaruh dalam membentuk dan memberi arti kepada anggota organisasi untuk berperilaku dan bertindak, yang diturunkan dari satu generasi ke generasi berikutnya sebagai karakter organisasi. Budaya organisasi adalah suatu sistem makna bersama yang dimana unsurnya meliputi materi, personal (SDM), pola hubungan sosial secara psikologi; nilai dan moral, yang kemudian diformulasikan menjadi sebuah konsep tertentu sebagai rujukan dalam menjalankan suatu wujud kinerja. 
Suatu budaya organisasi yang kuat ditandai oleh nilai-nilai inti organisasi yang dipegang kukuh dan disepakati secara luas. Semakin banyak anggota organisasi yang menerima nilai-nilai inti dan semakin besar komitmen mereka terhadap nilainilai tersebut, semakin kuat suatu budaya. Suatu budaya yang kuat jelas sekali akan memiliki pengaruh yang besar dalam sikap anggota organisasi dibandingkan dengan budaya yang lemah. Hasil spesifik dari suatu budaya yang kuat adalah keluar masuknya pekerja yang rendah. Suatu budaya yang rendah akan memperlihatkan kesepakatan yang tinggi mengenai tujuan organisasi di antara anggota-anggotanya. Kebulatan suara terhadap tujuan akan membentuk keterikatan, kesetiaan, dan komitmen organisasi (Stephen P. Robbins).

Sebuah organisasi seperti lembaga pendidikan akan menjalankan organisasinya khususnya dalam pelayanan administrasi pendidikan, termasuk di MAN I Makassar. Organisasi dalam Pelayanan administrasi pendidikan adalah adanya satu atau dua orang yang bekerjasama dalam sebuah tugas untuk menyelesaikan pekerjaan berdasarkan prinsip efisiensi dan efektifitas agar terwujudnya visi misi lembaga pendidikan (sekolah).

Berdasarkan uraian di atas, maka persoalan pokok yang akan dikaji adalah bagaimana implementasi budaya organisasi terhadap peningkatan pelayanan administrasi di MAN I Makassar dengan sub masalah: 1) Bagaimana budaya organisasi yang diimplementasikan di MAN I Makassar? 2) Bagaimana sistem pelayanan administrasi di MAN 1 Makassar? 3) Bagaimana dampak implementasi budaya organisasi dalam meningkatkan pelayanan administrasi di MAN 1 Makassar?

\section{TINJAUAN TEORETIS}

\section{Konsep Umum Budaya Organisasi}

Esensi lahirnya suatu konsep budaya organisasi adalah sebagai instrumen atau seperangkat asumsi dasar dan keyakinan yang dianut oleh anggota-anggota organisasi, yang kemudian dikembangkan dan diwariskan guna mengatasi masalahmasalah adaptasi eksternal dan masalah integrasi internal (Pabundu Tika). Pada umumnya, budaya dibangun dan diciptakan oleh pendiri atau lapisan pimpinan atas yang mendirikan atau merintis organisasi. Falsafah atau strategi yang ditetapkan oleh mereka lalu menjadi petunjuk dan pedoman bawahan mereka dalam melaksanakan tugas.

Penerapan budaya organisasi jika berhasil terterapkan akan membawa efek yang sangat signifikan dalam menentukan arah organisasi ke depannya seperti: a) Perasaan identitas dan menambah komitmen organisasi; b) Alat pengorganisasian anggota; c) Menguatkan nilai-nilai dalam organisasi; d) Mekanisme kontrol perilaku, pembeda antara satu organisasi dengan organisasi lainnya; e) Membangun rasa identitas bagi anggota organisasi; f) Mempermudah tumbuhnya komitmen; dan g) Meningkatkan kemantapan sistem sosial, sebagai perekat sosial, menuju integrasi organisasi. 
Budaya mengandung komponen keyakinan dan komponen nilai, hal ini disebabkan karena nilai adalah penghayatan anggota organisasi mengenai apa yang benar dan apa yang salah. Nilai, norma (keyakinan bersama), dan peran dalam suatu organisasi saling bergandengan satu sama lain. Nilai lebih menunjukkan kepercayaan tentang baik dan buruk dari seseorang. Dengan demikian nilai bagi seseorang itu merupakan pandangan atau anggapan atau kepercayaan mengenai sesuatu itu baik atau buruk. Menurut ahli psikologi sosial, suatu nilai mengandung kepercayaan bahwa suatu tindakan dan perbuatan dianggap patut ataupun tidak patut dilakukan oleh seseorang berdasarkan pertimbangan baik secara individu maupun sebagai masyarakat. Suatu sistem nilai dalam organisasi, mengandung kepercayaam organisasi tersebut tentang perbuatan yang dianggap patut dan tidak patut dilakukan.

Menurut M. Sashkin dan K. Kiser dalam Soewarso Hardjosoedarmo yang paling penting dalam hal nilai dan keyakinan adalah bahwa mereka berkaitan erat dengan tiga fungsi organisasi yang signifikan, yaitu penyesuaian diri pada perubahan, pencapaian tujuan, dan koordinasi kegiatan para anggota. Budaya dalam organisasi, yaitu himpunan nilai dan keyakinan akan menjamin bahwa dengan penyesuaian diri pada perubahan itu, organisasi akan selalu dapat memenuhi kebutuhan kustomer. Selanjutnya budaya organisasi juga menentukan bahwa tujuan yang harus dicapai organisasi adalah memenuhi kebutuhan customer.

Budaya organisasi mempunyai peran yang sangat besar dalam upaya mencapai tujuan organisasi. Akan tetapi budaya organisasi juga dapat menghambat perkembangan organisasi. Berikut ini dikemukakan peran budaya organisasi terhadap organisasi, anggota organisasi, dan mereka yang berhubungan dengan organisasi:

1. Identitas organisasi $\rightarrow$ Budaya organisasi berisi satu set karakteristik yang melukiskan organisasi dan membedakannya dengan organisasi yang lain. Budaya organisasi menunjukkan identitas organisasi kepada orang diluar organisasi.

2. Menyatukan organisasi $\rightarrow$ Budaya organisasi merupakan lem normatif yang merekatkan unsur-unsur organisasi menjadi satu. Norma, nilai-nilai, dan kode etik udaya organisasi menyatukan dan mengkoordinasi anggota organisasi. Ketika akan masuk menjadi anggota organisasi, para calon anggota organisasi mempunyai latar belakang budaya dan karakteristik yang berbeda. Agar dapat diterima sebagai anggota organisasi, mereka wajib menerima dan menerapkan budaya organisasi.

3. Reduksi konflik $\rightarrow$ Budaya organisasi sering dilukiskan sebagai semen atau lem yang menyatukan organisasi. Isi budaya mengembangkan kohesi sosial anggota organisasi yang mempunyai latar belakang berbeda, pola pikir, asumsi, dan filsafat organisasi yang sama memperkecil perbedaan dan terjadinya konflik diantara anggota organisasi. 
4. Motivasi $\rightarrow$ Budaya organisasi merupakan kekuatan tidak terlihat dibelakang faktor-faktor organisasi yang kelihatan dan dapat diobservasi. Budaya merupakan energi sosial yang membuat anggota organisasi untuk bertindak. Budaya organisasi memotivasi anggota organisasi untuk mencapai tujuan organisasi.

5. Kinerja organisasi $\rightarrow$ Budaya organisasi yang kondusif menciptakan, meningkatkan, dan memepertahankan kinerja tinggi. Budaya organisasi yang kondusif menciptakan kepuasan kerja, etos kerja, dan motivasi kerja karyawan (Hamidah Dwi).

\section{Konsep Umum Administrasi Pendidikan}

Administrasi pendidikan ialah segenap proses pengerahan dan pengintegrasian segala sesuatu. Baik personel, spiritual maupun material, yang bersangkut paut dengan pencapaian tujuan pendidikan. jadi, di dalam proses administrasi pendidikan segenap usah orang-orang yang terlibat di dalam proses pencapaian tujuan pendidikan itu diintegrasikan, diorganisasi dan dikoordinasikan secara efektif, dan semua materi yang diperlukan dan yang telah dimanfaatkan secara efisien (M. Ngalim Purwanto).

M. Ngalim Purwanto mengatakan administrasi pendidikan adalah suatu proses keseluruhan, kegiatan bersama, dalam bidang pendidikan yang meliputi: perencanaan, pengorganisasian, pengarahan, pelaporan, pengkoordinasian, pengawasan dan pembiayaan, dengan menggunakan atau memanfaatkan fasilitas yang tersedia, baik personel, materil, maupun spiritual, untuk mencapai tujuan pendidikan secara efektif dan efisien.

Mengacu pada batasan tersebut di atas terdapat beberapa hal yang berkenaan dengan administrasi. Seperti yang telah dikemukakan sebelumnya bahwa, pendidikan itu adalah terdapatnya suatu proses. Proses dalam hal ini dapat diartikan bahwa pendidikan terdiri dari serangkaian tindakan yang menuju ke suatu hasil tertentu. Tindakan tersebut biasanya saja suatu perbuatan yang tampak tetapi juga bisa saja tidak tampak. Pada umumnya tindakan dalam pendidikan itu merupakan tindakan yang tidak tampak nyata. Namun demikian, tindakan dalam pendidikan itu hampir selamanya bersifat formal, dalam artian tindakan-tindakan itu dibuat sengaja dan bertujuan (M. Daryanto).

Penerapan teori-teori administrasi pendidikan di sekolah adalah sebagai alat, maka yang menjadi tujuan administrasi pendidikan adalah meningkatkan efisiensi dan efektifitas penyelenggaraan kegiatan operasional kependidikan dalam mencapai tujuan Pendidikan (Nawawi, Hadari). George R. Terry tentang fungsi-fungsi pokok administrasi yang disingkat dengan POAC ini sama dengan pendapatpendapat sebelumnya, yaitu menempatkan Planning dan Organizing pada urutan pertama dan kedua. Sedangkan pada urutan ketiga dia menggunakan kata actuating sebagai kata yang mengandung makna memberi pengarahan atau aktualisasi 
kepada para pegawai arti pentingnya untuk melaksanakan tugas dengan sebaikbaiknya. Sehingga kata actuating itu setali tiga uang dengan kata directing dan commanding (Hisbul Muflihin).

Hadari Nawawi menyatakan, bahwa secara umum ruang lingkup administrasi berlaku juga di dalam administrasi pendidikan. Ruang lingkup tersebut meliputi bidang-bidang kegiatan sebagai berikut:

1. Manajemen Administrative (Admistrative Management), dalam kegiatan ini disebut juga "Management of administrative function" yakni kegiatan-kegiatan yang bertujuan mengarahkan agar semua orang dalam organisasi/kelompok kerjasama mengerjakan hal-hal yang tepat sesuai dengan tujuan yang hendak dicapai.

2. Manajemen Operatif (Operative Management). Bidang kegiatan ini disebut juga "management of operative function" yakni kegiatan-kegiatan yang bertujuan mengarahkan dan membina agar dalam mengerjakan pekerjaan yang menjadi beban tugas masing-masing setiap orang melaksanakan dengan tepat dan benar(M. Daryanto).

Suharsimi Arikunto mengatakan penjabaran administrasi yang telah dijelaskan di atas bahwasanya administrasi merupakan suatu usaha bersama sekelompok manusia untuk mencapai tujuan organisasi secara efektif dan efisien dengan menggunakan segala dana dan daya yang ada. Secara terinci pengertian administrasi mengandung beberapa kata inti yaitu: (1) usaha bersama, (2) sekelompok manusia, (3) tujuan organisasi, (4) efektif dan efisien, dan (5) dana dan daya.

Usaha: Administrasi adalah bagian dari suatu keseluruhan organisasi masyarakat. Ini diperlukan untuk menjaga kelestarian serta memperluas, meningkatkan taraf kesesuaian, efektivitas, dan produktivitas organisasi tersebut. Tentu saja untuk tujuannya ini harus ada kegiatan seperti merencanakan, melaksanakan, menilai dan melaporkan.

Sekelompok Manusia: Administrasi terjadi dalam suatu organisasi administrasi menjadikan segala sesuatu kegiatan yang direncanakannya dengan berkerja sama dan melalui orang lain.

Tujuan Organisasi: Administrasi adalah sarana untuk mencapai tujuan, administrasi merupakan layanan, bukan tujuan itu sendiri. Bagaimana bentuk administrasi yang dilakukan, sangat tergantung dari fungsi pendidikan dalam masyarakat.Seperti diketahui oleh setiap orang bahwa tujuan selalu berubah dari masa ke masa(Suharsimi Arikunto).

Menurut Moenir pada point ke tiga yaitu administrasi yang mempunyai unsur sistem organisasi patut digaris bawahi karena adanya proses pelayanan yang secara tersirat memiliki bentuknya tersendiri dan akan mempengaruhi integritas yang ada dalam sistem pelayanan administrasi jika tidak diperhatikan secara terperinci misalnya, bentuk pelayanan seperti (1) pelayanan dengan lisan, (2) Pelayanan 
melalui tulisan, (3) layanan dengan perbuatan dan tiga bentuk pelayanan ini tidak selamanya berdiri sendiri secara murni, melainkan sering berkombinasi. Jamal M.A pun menyatakan bahwa dalam peningkatan pelayanan administrasi pendidikan terkandung upaya-upaya, seperti mengendalikan proses yang berlangsung di sekolah (baik kurikuler maupun administrasi), melibatkan proses diagnosis, serta memerlukan partisipasi semua pihak (mulai dari kepala sekolah, guru, staf administrasi, siswa, orang tua/wali siswa, dan pakar).

\section{METODOLOGI PENELITIAN}

Jenis penelitian yang digunakan adalah penelitian kualitatif. Pendekatan yang digunakan dalam penelitian ini adalah pendekatan fenomenologis, pedagogis, psikologis dan sosiologis. Subjek dalam penilitian ini meliputi, kepala sekolah, wakil kepala sekolah, dan kepala bidang tata usaha, pengambilan data dalam penelitian ini adalah dilakukan secara langsung di Madrasah Aliyah Negeri I Makassar melalui pengumpulan data dengan melakukan teknik participan observation, interview, dan dokumentasi. Teknik pengolahan dan analisis data mengikuti cara yang dikemukakan oleh Miles dan Huberman, yaitu; reduksi data, display data, mengambil kesimpulan dan verifikasi. Pengujian keabsahan data dilakukan melalui proses trianggulasi.

\section{HASIL PENELITIAN DAN PEMBAHASAN}

\section{Budaya Organisasi yang diimplementasikan di MAN 1 Makassar}

Terbentuknya budaya organisasi di suatu lingkungan pendidikan dalam hal ini sekolah, sejatinya diperlukan sebuah kerjasama yang komprehensif dari setiap unsur sekolah baik itu kepala sekolah, pegawai/staf, guru, dan murid dalam mengimplementasikan nilai-nilai normatif yang telah disepakati atau nilai yang telah dijadikan sebuah acuan dalam menjaga stabilitas lingkungan sekolah secara psikologi dan sosial.

Konsep budaya organisasi sangat berperan penting dalam menjaga struktur mekanisme kerja secara teknis yang akan memperbaiki sistem administrasi sekolah, karena unsur budaya organisasi memiliki pengaruh kepada masing-masing personal dalam meningkatkan semangat kerja untuk menciptakan suatu lingkungan kerja yang kondusif.

Adapun budaya organisasi yang dibangun di MAN I Makassar dan diimplementasikan dalam mengelola sebuah organisasi pendidikan adalah:

\section{Kedisiplinan}

- Disiplin menegakkan peraturan

Kedisiplinan sudah menjadi perkara yang terkadang sangat sulit untuk dilaksanakan, disebabkan karena nilai kedisiplinan yang sifatnya sangat bersinggungan dengan kepribadian para personal sekolah memiliki dinamika yang 
berbeda-beda. Ada yang malas, hanya menuruti peraturan saja tanpa meresapi makna kedisiplinan itu secara mendalam, bahkan ekstrimnya ada yang acuh terhadap nilai-nilai kedisiplinan sehingga memicu konflik. Maka dari itu, untuk mengatasi persoalan emosional dalam penerapan kedisiplinan, perlu keputusan langsung dari atasan dalam hal ini kepala sekolah, agar ketentuan yang dikeluarkan disamping memiliki kekuatan konstitusional juga tidak serta merta diabaikan begitu saja oleh pihak personel sekolah. Sebagaimana yang dilakukan oleh kepala sekolah MAN 1 Makassar, Bapak Ramli Rasyid S.Ag, M.Pd.I, M.Ed pernyataannya:

"Budaya organisasi sangat memiliki peranan yang sangat signifikan dalam membentuk sebuah iklim kerja yang kondusif, maka dari itu kami disini (MAN 1 Makassar) membuat sebuah acuan sekaligus menjadi instruksi dalam menekankan nilai kedisiplinan dan nilai-nilai yang sifatnya membangun semangat kerja misalnya disiplin dalam hal mematuhi peraturan yang berlaku yang selanjutnya personal menginternalisasi secara bersama agar terbangun komitmen dalam menegakkan nilai-nilai yang telah disepakati".

Bapak Haris, SS. Selaku bidang kesiswaan, beliau juga menambahkan bahwa: Kedisiplinan di sini (MAN 1 Makassar) begitu sangat kita jaga, tidak hanya antar sesama pegawai dan unsur-unsur administrasi sekolah yang ada, bahkan siswa/siswi pun kami sangat menekankan sebuah nilai kedisiplinan khususnya dari segi kewajibannya sebagai siswa agar kiranya dapat mengikuti aturan yang berlaku di sekolah. seperti datang tepat waktu, menjaga kebersihan, hingga disiplin dalam menghormati guru dan sesamanya. Kami juga selalu menghimbau pada momentum tertentu, menyampaikan sebuah pesan positif bagi siswa, agar bagaimana membentuk moral siswa ke arah yang lebih baik.

- Displin dalam menjaga stabilitas pelayanan

Jelas nilai kedisiplinan adalah instrumen dalam membentuk suatu budaya organisasi agar menjadi sebuah acuan dalam melakukan sebuah kinerja yang maksimal. Tidak hanya itu nilai kedisiplinan juga memberikan sebuah makna edukasi dalam mengkonstruk kepribadian personal agar lebih inisiatif dalam melaksanakan pekerjaannya sebagaimana yang dijelaskan oleh ibu Fatma, S.Ag, MM. Selaku kepala bidang Tata Usaha Memberikan testimoni yang sama:

Nilai kedisiplinan adalah kunci dalam menjaga stabilitas pelayanan tata usaha, sebab hanya dengan nilai kedisiplinan kita tidak perlu khawatir akan adanya sebuah tindakan yang tidak diinginkan dalam proses administrasi khususnya dalam bidang tata usaha yang bersifat teknis operasional.

Dari aspek kedisiplinan disini kita bisa tergambarkan bahwa peran nilai kedisiplinan sangat menentukan sebuah iklim kerja yang terkendali karena dengan nilai kedisiplinan seluruh unsur sekolah yang terkait akan mampu menciptakan jiwa inisiatif masing-masing personal dalam menjaga kondusifitas iklim kerja tanpa ada rasa khawatir terjadinya tindakan yang merugikan suatu proses yang ada. 


\section{Kerjasama}

- Kerjasama dalam hal pemecahan masalah

Kerjasama adalah sebuah tindakan yang sangat bermanfaat dalam mencapai efisiensi dan efektifitas kerja. Mengapa demikian, karena makna dari sebuah kerjasama adalah bagaimana agar seluruh unsur yang ada mampu memberikan sebuah kontribusi terhadap satu masalah yang ada sehingga beban pekerjaan jadi ringan. Hal ini bisa kita amati dari proses yang dialami oleh ibu Fatma, S.Ag, MM.

...Mungkin karena kepercayaan yang telah tertanam kuat dimasing-masing personal, sehingga hampir seluruh permasalahan yang dihadapi yang sifatnya sensitif untuk diselesaikan, kami tidak menyelesaikannya secara sendirisendiri atau bidang perbidang, akan tetapi kami selalu mengambil jalan musyawarah di samping karena atas dasar kepercayaan telah terbangun. Juga agar lebih mempermudah memecahkan permasalahan melalui ide-ide yang bersumber dari berbagai personal.

Maksud yang sama juga diutarakan oleh bapak Ramli yang mengatakan:

Dalam sistem administrasi kami, nilai kerjasama di sini sangat terjalin dengan baik, contohnya kita bisa melihat para pegawai yang senantiasa saling membantu dalam mengarahkan para stakeholder/pihak yang berkepentingan terhadap sekolah ini dalam hal memenuhi apa yang diinginkan. Termasuk dalam menjalin sebuah hubungan kerjasama antara pegawai dan siswa dalam hal mejalin emosional melalui kegiatan-kegiatan yang sifatnya melibatkan secara keseluruhan unsur sekolah. dan pada intinya adalah nilai kerjasama sangat mampu memberikan sebuah efek positif dalam membantu pencapaian suatu kinerja.

Membangun budaya kerjasama antar personal merupakan bukanlah perkara yang mudah untuk dilakukan, karena hal tersebut cenderung dipengaruhi oleh unsur emosional dan psikologi individu yang relatif dan dimana dalam membangun kerangka kerjasama harus sebelumnya terjalin hubungan yang baik dan harmonis, dan mampu menyatukan suatu kesepahaman. Sebagaimana yang digambarkan oleh Dra. Hj. Hasmi Hasyim, M.Pd. selaku kepala bidang kurikulum yang menyatakan:

Nilai kerjasama dalam hal mewujudkan sebuah kinerja yang efektif dan efisien, sudah selayaknya menjadi metode yang tepat dalam penyelesaian tugas. Akan tetapi perlu kiranya dipahami bahwa nilai kerjasama harus dibangun di atas pondasi keharmonisan, dalam arti membangun kerjasama pertama-tama kita harus menyatukan visi dan menyatukan paham dalam mengerjakan segala sesuatu agar nilai kerjasama terwujud secara sempurna dan tidak terjadi polarisasi di antara individu-individu yang ada, dan menghindari potensi rusaknya hubungan kerjasama itu.

Seperti pada argumen-argumen responden sebelumnya, bahwa efektifitas nilai kerjasama dalam membangun kinerja yang produktif dan proaktif sangat 
berpengaruh dalam proses perkembangan dan kemajuan suatu sekolah, terlebih lagi akan membangun integritas sekolah memiliki ciri yang berkarakter dan menjadi pembeda diantara sekolah-sekolah lainnya.

\section{Teladan Kepemimpinan}

- Kepemimpinan sebagai contoh penerapan nilai

Budaya organisasi merupakan sebuah konsep sekaligus kerangka acuan yang berbasis nilai-nilai normatif dalam menciptakan sebuah karakteristik lembaga, akan tetapi tentu nilai-nilai tersebut harus berdasarkan pada pengendalian dan ketentuan dari pihak pimpinan atas atau dalam hal ini kepala sekolah. tak hanya itu, sebagai seorang pemimpin juga harus memberikan contoh atau patut menjadi teladan utama dalam penerapan nila-nilai yang telah dibentuk dan diberlakukan, agar para pimpinan beserta jajarannya merasa memiliki tanggung jawab moral untuk mewujudkan apa yang menjadi keputusan bersama.

Salah seorang siswa pernah peneliti tanyakan terkait persoalan kepemimpinan kepala sekolah, diapun menjawab:

Kami sangat segan terhadap kepala sekolah yang sedang saat ini menjabat, karena beliau sangat ramah dan sangat bisa berbaur dengan siswa dan siswi yang ada di MAN 1 Makassar. apalagi kalau beliau sedang kebetulan lewat dihadapan siswa-siswa yang ia temui, dia tak canggung senyum dan menanyakan kabar dan aktivitas yang kami lakukan sehingga kami merasa beliau adalah orang tua kami yang ke dua selain di rumah.

Membaca pendapat siswa terkait pandangan mereka terhadap kepala sekolahnya, membuktikan bahwa memang penting dan dibutuhkan sebuah pendekatan emosional sebagai seorang pemimpin dalam mempermudah proses penerapan budaya organisasi, karena dengan sebuah pendekatan emosional seseorang terkadang merasa segan terhadap seuatu kepribadian, sehingga mudah menjalin kerjasama untuk menerapkan sebuah kepentingan positif demi mewujudkan sistem dan suasana sekolah yang menjadi harapan bersama.

Bapak Haris, SS. Selaku bidang kesiswaan menyatakan sangat sering berdiskusi dengan kepala sekolah dalam proses pengendalian siswa kata beliau:

...Pak kepala sekolah, ketika saya bertemu, ada kalanya kami diskusi sepintas, terkait persoalan bagaimana cara menanamkan nilai-nilai positif kepada siswa yang boleh dikata nilai-nilai positif tersebut tidak membatasi ruang berekplorasinya. Misalnya saja kami di bidang kesiswaan terkadang mengarahkan kepada siswa-siswa ketika mereka lagi tidak ada akifitas pembelajaran diluar jam istirahat, agar membaca buku, ataukah kami menginstruksikan mereka untuk ke perpustakaan untuk kemudian mereka membaca aneka buku yang tersedia. Artinya kami dengan kepala sekolah sudah menjadi partner yang bukan saja hanya sebatas struktural saja, akan tetapi kepala sekolah bagi kami bisa menjadi teman yang adaptif. 
Ibu Fatmah S.Ag, MM juga menambahkan:

...sudah jelas bahwa yang menjadi kepala pimpinan dalam suatu sekolah adalah kepala sekolah. kepala sekolah yang sejatinya merupakan pemimpin yang sifatnya struktural, tidak juga harus mengikuti apa yang telah dikonsepkan dalam hierarki kepemimpinan, akan tetapi pemimpin harus bersifat improfisasi diluar dari apa yang menjadi kewajibannya. Dalam arti bahwa kepala sekolah harus menggunakan wewenang yang tidak hanya terfokus pada suatu permasalahan yang formal, akan tetapi kepala sekolah harus menjadi teladan dan juga menjadi seorang "bapak" yang senantiasa memberikan suatu pendekatan emosional yang sesekali memantik hubungan keakraban para pimpinannya. Dan itu bisa terlihat dari kepribadian kepala sekolah kami yang setiap saat kami amati, berjalan untuk memastikan apakah semuanya baik-baik saja dalam lingkungan sekolah. dan sesekali menanyakan apa yang menjadi kendala pada masing-masing bidang.

Berangkat dari pandangan-pandangan yang ada pada pembahasan kepemimpinan jelas memberikan suatu refleksi kepada peneliti khususnya para pembaca bahwa keteladanan serta sifat kepemimpinan yang dimiliki oleh kepala sekolah sudah menjadi suatu landasan dalam mengkonstruk suatu budaya organisasi. dan dari beberapa pandangan yang menyatakan bahwa seringkali kepala sekolah menggunakan suatu pendekatan emosional yang kiranya cukup untuk menjalin dan membangun kerjasama dalam merancang budaya organsasi ke arah yang diharapkan.

\section{Sistem Pelayanan Administrasi di MAN 1 Makassar}

Menjaga kualitas sekolah agar tetap menjadi yang terbaik adalah hal yang sangat diantisipasi karena bisa saja ketika tidak ada rasa perhatian tinggi akan membawa integritas suatu sekolah kepada stigma negatif masyarakat ketika terjadi suatu kesalahan dalam perencanaannya, termasuk dalam merencanakan bagaimana model pelayanan administrasi yang dimana dalam aspek ini (administrasi) sangat bersentuhan langsung kepada stakeholder yang sedang merasakan pelayanan sekolah itu sendiri. Pastinya ketika didapati hal-hal yang mengganjal dalam proses administrasinya, tidak menutup kemungkinan citra sekolah akan menurun dan akan menimbulkan sebuah sikap antipati masyarakat di tengah-tengah lingkugan sekolah itu berada.

Dalam pembahasan model pelayanan administrasi pendidikan di MAN 1 Makassar terdapat beberapa prinsip yang menjadikan model pelayanan administrasi di MAN 1 Makassar terlihat ideal diantaranya:

\section{Pengutamaan Tugas}

Administrator bertanggung jawab dan berpegang teguh pada amanah untuk mengutamakan tugasnya. Pelaksanaan tugas tidak didasarkan pada pesan sponsor, melainkan atas dasar skala prioritas. Apabila prinsip ini dilanggar, beberapa prinsip 
dalam administrasi akan terpengaruhi bahkan sampai menimbulkan sebuah pemborosan biaya.

Kepala sekolah mengungkapkan terkait persoalan pengutamaan tugas ini:

Dalam sistem pelayanan administrasi kami disini secara personal kami tidak menuntut akan berbagai hal hingga memunculkan suasana yang kaku dalam bekerja. Akan tetapi disisi lain kami juga tidak ingin seluruh pekerjaan memiliki kendala hingga menimbulkan sebuah pemborosan dalam penggunaan sumber daya, maka dari itu saya sebagai atasan yang bertanggung jawab secara keseluruhan atas segala sesuatu yang terjadi di dalam prosesnya hanya cukup memberikan penekanan kepada para pegawai (guru/staf) untuk tetap memprioritaskan pekerjaan pokoknya, di samping mengerjakan pekerjaan yang sifatnya menunjang.

Ibu Fatmah S.Ag, MM juga menambahkan:

Pelaksanaan sebuah pengutamaan tugas disini merupakan hal yang pokok dan prioritas, salah satunya pengutamaan dari segi pelayanan umum. Baik dari segi pengelolaan berkas administrastif untuk keperluan yang prinsipil serta aktivitas pelayanan yang prima dimana hal pelayanan tersebut merupakan ciri khas kami pada bidang tata usaha untuk mengakomodir seluruh kepentingan stakeholder baik internal maupun eksternal.

Pengutamaan pekerjaan sebuah tugas memang merupakan hal sangat patut diperhatikan secara maksimal. Terkadang dari hal tersebut timbul sebuah pemicu permasalahan yang dikarenakan tidak berjalannya sebuah sistem pokok yang sudah sepatutnya harus dikerjakan setiap hari seperti pelayanan yang harus maksimal dalam melayani stakeholder. Seperti contoh kasus misalnya seluruh personel terkadanag asyik dengan kepentingannya masing-masing dan akhirnya mengenyampingkan apa yang menjadi tugasnya pokonya dan berujung kepada sistem pelayanan yang buruk.

\section{Prinsip Pengelolaan}

Pengelolaan dalam pengertiannya yang sepintas diketahui sebagai suatu cara kerja bagaimana segala sesuatu yang dikerjakan bisa secara rapi dan terstruktur untuk menghindari adanya permasalahan dalam suatu sistem yang berjalan. Prinsip pengelolaan yang teradapat di MAN 1 Makassar, yang peniliti amati secara objektif sudah mendekati tataran ideal mulai dari tertatanya berkas-berkas (database) para pegawai yang bekerja, proses operasional yang begitu tertib, para pegawai yang begitu disiplin dalam memberikan sebuah pelayanan yang ramah terhadap stakeholder.

Namun itu semua masih sebatas pengamatan saya sebagai peneliti dan yang tahu pasti tentunya tentang seputar pengelolaan secara keseluruhan adalah para personel yang bekerja. Maka dari itu saya terutama mewawancarai bapak Ramli selaku kepala sekolah yang memiliki pengaruh secara keseluruhan terkait teknik 
atau pendekatan apa yang dipakai dalam pengelolaan administrasi sehingga begitu tertata dengan baik. beliau mengatakan:

Mungkin anda melihat secara objektif bahwa terkelolanya dengan baik seluruh perangkat administrasi yang ada, bukanlah murni dari saya pribadi selaku kepala sekolah yang begitu sangat menekankan kepada seluruh personil untuk bisa bekerja secara baik. akan tetapi berangkat dari kesadaran masing-masing personal administrator akan pentingnya sebuah pengelolaan secara baik, serta dari pengalaman-pengalaman pendidikan yang dilaluinya. Ini menandakan bagi kami bahwa dalam proses atau sistem pengelolaan tidak melulu soal instruksi, melainkan masing-masing personel sudah mengetahui dampak ketika suatu pengelolaan administrasi berjalan dengan baik, akan mempengaruhi citra sekolah begitupun konsekuensi sebaliknya.

Prinsip pengelolaan merupakan salah satu faktor yang juga mendukung dalam menentukan suatu kemajuan atau perkembangan sekolah. Sebab dalam konteks kebijakan pendidikan, yang menjadi unsur dalam menilai perkembangan sekolah adalah dilihat dari proses pengelolaannya. Baik pengelolaan dari segi arsip, invetarisir, pengentrolan dan lain sebagainya. Hal yang senada kemudian juga terdengar dari seorang siswa yang mungkin tidak memiliki pengaruh sama sekali atas prinsip pengelolaan, akan tetapi setidaknya peniliti memasukkannya sebagai pertanda, bahwa pengelolaan administrasi yang dilakukan oleh pihak administrator juga bisa langsung dirasakan oleh seluruh elemen sekolah. siswa tersebut mengungkapkan:

Terkadang kalau kami tak sengaja lewat di depan ruang tata usaha pada waktu pagi, kami melihat beberapa pegawai tata usaha selalu menata dan membersihkan seluruh arsip dan inventaris tata usaha yang ada di dalam ruangan itu. Dan juga ketika kami datang ke ruang tata usaha untuk mengurus suatu keperluan yang sifatnya administrasi, semuanya berjalan dengan lancar dan cepat. Mungkin itu suatu kewajaran, karena tata kelola yang mungkin dilakukan hampir setiap harinya, sehingga memiliki pengaruh yang baik dalam proses pengelolaan dan pelayanannya.

Hal yang mungkin senada juga keluar dari argumen Ibu Fatmah selaku Kepala Tata Usaha MAN 1 Makassar:

Setiap pagi, sebelum kami melakukan seluruh tugas yang ada, kami selalu menekankan untuk selalu mengawali dengan aktivitas bersih-bersih, dan juga menata yang perlu ditata seperti database, inventarisir tata usaha dan lain sebagainya. Upaya ini sudah menjadi rutinitas keseharian kami, disamping untuk menjaga nilai kedisiplinan dan nilai kebersihan. Juga sebagai tanda kesiapan bahwa kami sudah siap untuk bekerja. Kami berpikir, ketika upaya tersebut tidak dilakukan, khawatir akan menimbulkan permasalahan yang tidak diinginkan. Misalnya dalam mencari sebuah data atau barang-barang 
yang dibutuhkan terkadang kami tidak menemukannya, padahal suatu waktu akan dibutuhkan sekali keberadaannya.

Prinsip pengelolaan, mungkin secara praktis, kita melihatnya hanya sebatas sebuah upaya penataan dan pengendalian terhadap suatu materi maupun nonmateri. Akan tetapi kita tidak pernah melihat secara substansial bahwa upaya pengelolaan yang dilakukan adalah sejatinya untuk menjaga stabilitas kinerja administrator dalam mengakomodir segala kepentingan yang berkenaan dengan administrasi itu sendiri agar tidak terjadi suatu distorsi dalam prosesnya dan juga membantu sebuah kesistematisan kinerja administrasi.

\section{Efisiensi dan Efektifitas}

Secara teoritik, konsep efisiensi sebagai suatu prinsip dalam aspek administrasi, adalah suatu upaya dalam mengelola dan memberdayakan segala sumber daya yang ada (materi dan non-materi) secara maksimal dalam mencapai tujuan yang diinginkan secara cepat dan tepat. Prinsip efisiensi sangat begitu memberikan sebuah peranan yang penting dalam mempengaruhi produktivitas administrasi, terutama dalam proses pelayanannya, sebab prinsip nilai efisiensi jika ingin betul dijadikan sebuah komitmen yang bukan sekedar teori, tentunya akan memberikan sebuah tuntunan dalam proses kinerja yang efektif atau tepat sasaran tanpa ada sedikitpun upaya yang sia-sia.

Ibu Hasmi selaku wakil kepala sekolah bidang kurikulum mengatakan, bahwa: Prinsip efisiensi yang kami ketahui, tidak hanya sekedar teori yang seolah menjadi sebuah rujukan, akan tetapi kami paham betul arti dampak prinsip efisiensi yang akan mewujudkan kondisi kinerja yang sistematis ketika kami menerapkannya.

Hal yang sama juga dirasakan oleh ibu Fatma:

Sudah menjadi sebuah kewajiban bagi kami khususnya sebagai pengelola administrasi di bidang tata usaha agar menjadikan prinsip efisiensi sebagai suatu komitmen dalam menciptakan kondisi kerja administrasi yang efektif. Apalagi kami yang bekerja dalam bidang administrasi yang menuntut kegiatan operasional dan kompleks. Membutuhkan keterampilan ekstra dalam memberdayakan seluruh sumber daya secara tepat guna. Dan hal itu bisa kami lakukan lagi-lagi dengan cara menekankan secara terus-menerus kepada para personil untuk tetap memperhatikan proses kerja, apakah sudah mencapai nilai efisiensi atau tidak.

Prinsip efisiensi juga tidak hanya memberikan efektifitas dalam penggunaan seluruh sumber daya yang ada guna mewujudkan sebuah tujuan, akan tetapi juga memberikan sebuah kelancaran dalam urusan proses administrasi yang sangat menuntut kerja-kerja teknis agar dapat terselesaikan secara hemat tanpa harus mengeluarkan akomodasi yang lebih. Artinya dengan penerapan prinsip efisiensi dalam administrasi memacu para administrator menggunakan seluruh peralatan 
dan perangkat yang ada meskipun sifatnya terbatas namun tetap menghasilkan sebuah hasil yang maksimal.

\section{Dampak Implementasi Budaya Organisasi dalam Meningkatkan Pelayanan Administrasi di MAN 1 Makassar}

Setelah kita membaca dari poin-poin pembahasan, yang begitu banyak memaparkan indikator tercapainya sebuah budaya organisasi dan juga sistem pelayanan adminstrasi yang berjalan di MAN 1 Makassar, maka dalam point ketiga ini akan memberikan sebuah pemahaman tentang arti daripada manfaat yang dirasakan ketika pengimplementasian budaya organisasi berhasil diterapkan.

Ramli Rasyid S.Ag, M.Pd.I, M.Ed memberikan sebuah testimoni:

Terwujudnya konsep budaya organisasi di sekolah kami, tentu memberikan efek yang sangat signifikan khususnya sangat membantu dari segi hubungan individu dan juga sistem operasional. Meskipun nyatanya pada pengimplementasian budaya organsasi terkadang lebih banyak mengandung unsur keabstrakan dalam artian tidak nampak oleh teks (aturan tertulis) hanya saja kami meyakini akan sebuah nilai positif yang dilakukan, kelak akan membawa sekolah kami didalamnya terbangun sebuah keharmonisan dari seluruh elemen personal sekolah baik secara internal maupun eksternal.

Ibu Dra. Hasmi Hasyim, M.Pd. juga menuturkan:

Jika ditanyakan soal dampak mengenai penerapan budaya organisasi, tentu akan memberikan sebuah pengaruh yang sangat menguntungkan bagi kami. Terutama dalam melancarkan seluruh sistem koordinasi, dimana dibutuhkan sebuah komunikasi yang baik, disinilah peran budaya organisasi dibutuhkan, yang dimana sebelumnya saya mengatakan bahwa budaya organisasi adalah sebuah proses penerapan nilai-nilai positif, dan dalam proses komunikasi itu dibutuhkan sebuah nilai positif semisal, kerjasama yang baik antar personal sekolah dan komunikasi yang terjalin secara santun dan sopan.

Dampak budaya organisasi cukup memberikan sebuah pengaruh yang sangat menonjol dalam sistem admnistrasi untuk menciptakan sebuah nilai positif, tentunya ini adalah awal dari terbentuknya sebuah karakteristik pembeda dari sekolah lainnya yang kemudian menjadi instrumen dalam menegakkan sebuah aturan yang telah disepakati dan juga menjadikan seluruh personal sekolah mampu bersaing secara berkualitas.

Fatma, S.Ag, MM mengungkapkan:

...Kalau dampak budaya organisasi yang kami rasakan, sejauh ini sangat memberikan sebuah sumbangsi penting atas kelancaran administrasi operasional tata usaha. Karena dengan budaya organisasi, kesadaran akan tanggung jawab yang telah dimiliki masing-masing personal di bidang tata usaha dapat terlaksana dengan baik. hal tersebut terjadi karena dampak 
budaya organisasi memantik kesadaran para personal untuk memaknai akan arti sebuah nilai-nilai yang diterapkan untuk mencapai efektifitas kinerja.

Dengan adanya seluruh rangkuman dialog yang peneliti lakukan untuk mengetahui seberapa efektif dampak pengimplementasian budaya organisasi dalam meningkatkan administrasi pendidikan khususnya di MAN 1 Makassar. peneliti sedikit ingin menyimpulkan, bahwasanya dalam sebuah proses administrasi yang dimana pengertiannya secara garis besar lebih menekankan kepada adanya sebuah proses kerjasama antara satu atau lebih orang untuk menyelesaikan sebuah tujuan untuk kemaslahatan umum, dari pengertiannya sangat berimplikasi untuk kita tekankan sebuah nilai-nilai kemanusiaan, sebab ruang lingkup pekerjaannya disamping sifatnya teknis ada kemudian nilai kemanusiaan yang harus tetap dijaga sebagai makhluk sosial, yang dimana indikator pelaksanaanya sangat menyimpan nilai-nilai filosofis yang tidak mungkin untuk dituangkan dalam bentuk aturan formal seperti, menjaga komunikasi yang baik, ramah terhadap sesama manusia, dan serta saling menghormati.

Dalam bentuk nilai-nilai kemanusiaan inilah yang kemudian akan menjadi acuan dalam menjaga stabilitas disamping telah di dukung oleh teori-teori administrasi yang tepat, juga perlu diingat bahwa kembali kepada sebuah substansi dari pekerjaan itu ada manusia yang bekerja dengan berbagai dinamika sosial yang bersangkutan langsung dengan psikologis mereka dan ini mustahil rasanya ketika konsep administrasi yang juga sepenuhnya untuk ditawarkan. Perlu ada konsep yang dapat mengatur secara eksplisit nilai-nilai kemanusiaan itu agar dapat terkendali, disamping tetap menjaga nilai-nilai prinsipil administrasi yakni konsep budaya organsasi yang mengatur segala lalu lintas sosial personal.

\section{KESIMPULAN DAN IMPLIKASI PENELITIAN}

Berdasarkan hasil penelitian yang telah dikemukakan pada pembahasan sebelumnya, maka dari itu, penulis akan memberikan suatu kesimpulan bahwa MAN 1 Makassar telah menerapkan konsep budaya organisasi dalam meningkatkan pelayanan administrasi pendidikan, berangkat dari hal tersebut, dapat ditarik kesimpulan bahwa:

1. Budaya organisasi telah terimplementasikan di MAN 1 Makassar dalam bentuk penerapan budaya kedisiplinan, kerjasama, keteladanan kepemimpinan sebagai penunjang dalam melancarkan seluruh sistem kinerja setiap personal dalam menyelesaikan seluruh pekerjaan agar terjadi sebuah keharmonisan yang berdampak pada lancarnya sistem komunikasi pelayanan serta terjalinnya rasa solidaritas yang tinggi dari setiap unsur sekolah yang ada di MAN 1 Makassar. Penerapannya dan memiliki efek yang memuaskan yang terlihat dari harmonisnya sebuah pelayanan terhadap stakeholder serta terjalinnya dengan baik sebuah hubungan koordinasi antar sesama pegawai dalam menyelesaikan sebuah tugas dan amanah. 
2. Sistem pelayanan administrasi di MAN 1 Makassar meliputi sistem pengutamaan tugas, pengelolaan, serta pencapaian efisiensi dan efektifitas yang kemudiannya juga bertransformasi sebagai sebuah prinsip dalam meningkatkan sebuah kualitas pelayanan administrasinya. konsep ini memiliki kontribusi yang sangat membantu sekolah MAN 1 Makassar ini dalam meningkatkan kualitas pelayanan administrasinya menuju pada peningkatan sebuah akreditasinya.

3. Implementasi budaya organisasi telah berdampak pada peningkatan pelayanan administrasi pendidikan. Dampak yang kemudian dirasakan oleh seluruh elemen personal sekolah atas konsep budaya organisasi mungkin dapat diamati secara bersama-sama yang banyak merangkum argumen dan memberikan kesaksian atau testimoni untuk menjelaskan betapa efektifnya sebuah proses administrasi ketika konsep budaya organisasi mampu dikolaborasikan dengan konsep administrasi. Peneliti menyimpulkan adanya sebuah persinggungan antara nilai filosifis yang dimiliki oleh konsep budaya organisasi dari suatu aktifitas dan adanya nilai praksis yang kemudian mewujudkan nilai yang ada secara menyeluruh khusunya berdampak pada terciptanya efektifitas pelayanan administrasi di MAN 1 Makassar.

Berdasarkan hasil penelitian yang berkaitan dengan implementasi budaya organisasi dalam meningkatkan pelayanan administrasi di Madrasah Aliyah Negeri 1 Makassar, maka konsep budaya organisasi mempunyai peranan yang sangat penting dalam meningkatkan pelayanan administrasi. Penulis sedikit ingin memberikan saran melalui tulisan ini antara lain sebagai berikut:

1. Diharapkan kepada pihak sekolah Madrasah Aliyah Negeri 1 Makasssar dapat meningkatkan pelayanan administrasinya secara maksimal dengan tetap merujuk kepada nilai-nilai kemanusiaan sebagaimana yang dimaksud dalam konsep budaya organisasi serta dapat menerapkannya secara efektif dan efesien.

2. Dalam meningkatkan seluruh upaya atau aktifitas administrasi di MAN 1 Makassar hendaknya mampu mengharmoniskan kedua konsep yaitu budaya organisasi dan prinsip sistem yang terkandung dalam teori administrasi agar kemudian menghasilkan sebuah karakteristik dalam proses pelayanannya dan tentu akan mempengaruhi kualitas sekolah dalam aspek tertentu. 


\section{DAFTAR PUSTAKA}

Arikunto, Suharsimi. Organisasi dan Administrasi Pendidikan Teknologi dan Kejuruan. Cet.II, Jakarta: PT RajaGrafindo Persada, 1993.

Chatab Nevizond, Profil Budaya Organisasi, Cet.I, Bandung: Alfabeta, 2007.

Danim, Sudarwan. Danim, Yunan. Administrasi Sekolah \& Manajemen Kelas, Cet.I, Bandung: Pustaka Setia, 2010.

Daryanto, H.M. Administrasi Pendidikan. Cet.I, Jakarta: PT RINEKA CIPTA, 1998.

Daryanto. Administrasi dan Manajemen Sekolah. Cet.I, Jakarta: PT RINEKA CIPTA, 2013.

Engkoswara. Komariah, Aan. Administrasi Pendidikan. Cet.III, Bandung: ALFABETA, 2012.

Hardjosoedarmo, Soewarso. Total Quality Management. Cet.III, Yogyakarta: Penerbit Andi, 2004.

Ma'mur, Asmani, Jamal. Tips Menjadi Kepala Sekolah Profesional, Cet.I, Jogjakarta: Diva Press, 2012.

Malayu, Hasibuan, S.P. Organisasi \& Motivasi. Cet.IV, Jakarta: PT Bumi Aksara 2003.

Moenir. Manajemen Pelayanan Umum di Indonesia, Cet.VIII, Jakarta: Bumi Aksara, 2008.

Muflihin, Hisbul. Administrasi Pendidikan, Cet.l, Klaten: CV GEMA NUSA, 2015.

Muhammad, Arni. Komunikasi Organisasi, Cet.IX, Jakarta: Bumi Aksara, 2008.

Nawawi, Hadari. IImu Administrasi. Cet.I, Jakarta: Ghalia Indonesia, 1994.

Saefullah. Manajemen Pendidikan Islam. Cet.1, Bandung: Pustaka Setia, 2012.

Sagala, Syaiful. Adminstrasi Pendidikan Kontemporer. Cet.VII, Bandung: ALFABETA, 2013.

Sondang, Siagian P. Filsafat Administrasi. Cet.Il, Jakarta: PT Bumi Aksara, 2004.

Stephen, Robbins P. perilaku organisasi. Cet.V, Jakarta: Erlangga, 2002.

Subeki, Ridhotullah. Mohammad, Jauhar. Pengantar Manajemen. Cet.II, Jakarta: Prestasi Pustaka, 2015.

Sutarto. Pengertian, Kedudukan, dan Perincian IImu Adminitrasi. Cet.III, Yogyakarta: Liberty Yogyakarta, 1993.

Thoha, Miftah. Pembinaan Organisasi. Cet.III, Jakarta: PT RajaGrafindo Persada, 2002.

Tika, Pabundu. Budaya Organisasi dan Peningkatan Kinerja Perusahaan. Cet.IV, Jakarta: PT Bumi Aksara, 2012. 
Tim Dosen Administrasi Pendidikan Universitas Pendidikan Indonesia, Manajamen Pendidikan, Cet.VIII, Bandung: Alfabeta, 2015.

Torang, Syamsir. Organisasi \& Manajemen, Cet.III, Bandung: Alfabeta, 2016. 